\title{
Effects of great bustard (Otis tarda) gut passage on black nightshade (Solanum nigrum) seed germination
}

\author{
C. Bravo $^{1 *}$, S. Velilla ${ }^{2}$, L.M. Bautista ${ }^{1}$ and B. Peco ${ }^{2}$ \\ ${ }^{1}$ Department of Evolutionary Ecology, Museo Nacional de Ciencias Naturales-CSIC, C/José Gutiérrez Abascal, 2. \\ 28006 Madrid, Spain; ${ }^{2}$ Department of Ecology, Universidad Autónoma de Madrid, C/Darwin, Ciudad Universitaria \\ Cantoblanco, 28049 Madrid, Spain
}

(Received 1 February 2014; accepted after revision 13 April 2014; first published online 22 May 2014)

\begin{abstract}
Birds are important seed dispersers for fleshy fruits through their transportation of ingested seeds. The seeds of many species germinate faster and in greater proportions after passing through a digestive tract, although the effects of this passage vary amongst bird and plant species. Many factors determine the germination success of ingested seeds, such as seed scarification during the digestion process, the fertilizing effect of droppings and the removal of pulp surrounding the seeds. In central Spain, the great bustard (Otis tarda) may act as a disperser of European black nightshade (Solanum nigrum). We analysed the germination success of ingested and non-ingested $S$. nigrum seeds. The fertilizing effect of bustard droppings and the disinhibition effect of the removal of Solanum pulp on final germination percentage, germination speed and viability were also assessed. Although ingested seeds germinated faster than non-ingested seeds, the former showed a lower germination percentage than the latter: $80-87 \%$ versus $99 \%$. Droppings and fruit pulp showed no effect on germination enhancement, except in one aspect: the germination speed of non-ingested seeds decreased when they were sprayed with a fruit extract. We confirm that seeds ingested by great bustards had lower germination success than non-ingested seeds. Although seed ingestion by great bustards reduced seedling emergence, the number of emerged seedlings was still quite large. Thus, great bustards may play a role as a $S$. nigrum seed dispersal vector.
\end{abstract}

Keywords: agricultural ecosystems, endozoochorous relationship, germination success, Mediterranean, seed dispersal, weed

${ }^{*}$ Correspondence

Email: c.bravo@mncn.csic.es

\section{Introduction}

Seed dispersal and plant disperser interactions play an important role in plant community structure, population dynamics and plant species diversity. Understanding how frugivores affect germination of endozoochorous plant species is of great relevance from ecological and evolutionary perspectives (Howe and Smallwood, 1982; Traveset et al., 2007). The consumption of fleshy fruits by vertebrates may be regarded as a mutualistic relationship in which a plant aims to disperse its seeds surrounded by edible and nutritious fruit (Estrada and Fleming, 1986). This mutualistic relationship is generally quantified in terms of seed dispersal effectiveness (SDE), which is determined by quantity (i.e. number of dispersed seed) and quality (i.e. condition of the dispersed seeds or probability of seeds reaching an adult stage) components (Schupp, 1993; Schupp et al., 2010). The quality component of dispersal is influenced by the quality of the treatment, such as seed scarification, during the digestion process, and by the quality of seed deposition, such as the fertilizing effect of manure and chemical disinhibition by frugivory, i.e. removal of pulp surrounding the seeds (Traveset et al., 2007).

Many characteristics of animal dispersers, such as feeding behaviour (diet type) and physiology (body mass, retention time), may influence the scarification of the seed coat when passing through the gut (Jackson, 1992; Afik and Karasov, 1995; Traveset et al., 2007). Retention time varies with diet type (shorter in frugivores) and body size (longer in large animals) (Jackson, 1992; Afik and Karasov, 1995). There is a greater risk of digestive damage to seeds in animals with long retention times (Jordano and Schupp, 2000). Scarification can be disadvantageous because the digestive fluid to which seeds are exposed may damage the embryo and thus decrease seed viability, but it can also help germination due to the scarification effect on hard-coated seeds (Traveset et al., 2007). 
Ingested seeds may germinate better than noningested seeds due to the presence of manure (Dinerstein and Wemmer, 1988; Traveset et al., 2001). The fertilizing function of manure has been acknowledged by seed dispersal experts (Willson and Traveset, 2000) and supported by experimental evidence (Traveset et al., 2007; Carmona et al., 2013). However, the germination success of seeds may be reduced if manure facilitates the growth of microorganisms (fungi and bacteria) (Meyer and Witmer, 1998).

The compounds in fruit pulp can reduce germination success by blocking biochemical pathways of germination. By the disinhibition effect (Samuels and Levey, 2005; Traveset et al., 2007), ingested seeds may germinate better than non-ingested ones when the pulp surrounding seed is removed during gut passage. The excreted seeds are released from the blockage, and also from the osmotic and light regimes within the fruit pulp, which can reduce and even suppress germination (Traveset et al., 2007). The disinhibition effect derived from the elimination of the fruit pulp may differ between disperser species, since the potentially significant effects of fruit pulp elimination are inherently part of the 'gut passage' process.

Among disperser birds, seed dispersal effectiveness is particularly well-known in frugivorous passerine species (Herrera, 2002; Traveset et al., 2007). It has been reported that the European black nightshade (Solanum nigrum) is commonly dispersed in the western Palaeartic by medium-sized $(<0.2 \mathrm{~kg})$ frugivorous birds, such as Eurasian blackbirds (Turdus merula) and European starlings (Sturnus vulgaris) (Barnea et al., 1990; Clergeau, 1992; Rodríguez-Pérez et al., 2005). In contrast, dispersal of $S$. nigrum seeds ingested by omnivorous nonpasserine bird species is poorly documented. On the Iberian Peninsula, the great bustard (Otis tarda), one of the world's heaviest flying birds $(5-10 \mathrm{~kg}$ ) (Alonso et al., 2009), is an occasional feeder on S. nigrum (roughly $5-28 \%$ presence of $S$. nigrum in its summer diet) (Lucio, 1985; Lane et al., 1999; Bravo et al., 2012). The great bustard may thus play a major, but still unknown, role as a seed dispersal vector of $S$. nigrum.

In this context, our goals were to verify: (1) the effect of the great bustard digestive tract on seed germination rate and ratio, as well as on seed viability and seed-coat damage; (2) the fertilizing effect of bustard droppings; and (3) the disinhibition effect of fruit pulp removal on the final germination percentage and germination speed of $S$. nigrum seeds.

\section{Materials and methods}

\section{Study site and sampling procedure}

The fieldwork was conducted on agricultural farmland in central Spain $\left(29^{\circ} 40^{\prime} \mathrm{N}, 3^{\circ} 28^{\prime} \mathrm{W}\right)$, where the populations of great bustards and S. nigrum are widely distributed. The habitat is mainly cultivated for cereal production (Triticum aestivum and Hordeum vulgare), with a few fields used for other agricultural crops (legumes, olives, sunflowers and grape vines). S. nigrum is distributed on the edges of fields and in stubble. The climate is continental Mediterranean, with an annual precipitation (mean $\pm \mathrm{SD}$ ) of $442.5 \pm 125.5 \mathrm{~mm}$, and a mean annual temperature of $14.4^{\circ} \mathrm{C}$ (maximum and minimum temperatures, $42.2^{\circ} \mathrm{C}$ and $-14.8^{\circ} \mathrm{C}$ ). Maximum temperatures and minimum precipitation are reached during July and August $\left(24.5^{\circ} \mathrm{C}, 50 \mathrm{~mm}^{3}\right)$, coinciding with the fruiting period of $S$. nigrum. All climatic data were taken from AEMET (2014).

Great bustard droppings and mature fruits of S. nigrum were collected in August 2012. Three flocks of females (totalling 84 individuals) were located and tracked from afternoon to sunset to detect their roosting sites. Fresh droppings $(n=62)$ were collected from these sites at the following sunrise (Bautista et al., 2013). We did not use a fixed transect because great bustards are gregarious and have no fixed roosting sites at night, nor can the midday resting sites be predicted, forcing the collection of droppings at a new site each time. We collected fewer droppings than birds to limit the chances of pseudo-replication. Seeds were separated from each dropping with the aid of binocular microscopes $(20 \times)$, immediately washed with deionized water, gently dried with laboratory blotting paper and stored in paper bags in a dark room at constant temperature $\left(4^{\circ} \mathrm{C}\right)$. Darkroom humidity was minimized by bags of silica gel. Non-ingested seeds were collected in the same crop fields or nearby (within $500 \mathrm{~m}$ ) of the dropping collection point. We harvested 4-5 intact mature fruits per Solanum individual, totalling 260 mature fruits from 61 individuals. In the lab, the seeds were removed from the fruits and the same cleaning and storage protocol was applied.

To assess the fertilizing and disinhibition effects, an extract of bustard droppings and S. nigrum fruits was obtained. A random sample of 349 mature fruits and 5 droppings were oven-dried $\left(80^{\circ} \mathrm{C} ; 72 \mathrm{~h}\right)$. Dry droppings $(6.72 \mathrm{~g})$ and dry fruits $(12.01 \mathrm{~g})$ were mashed, weighed and diluted with deionized water at 1:10. The effects of gut passage on the seed coat were also evaluated visually by scanning electron microscopy (SEM) (Samuels and Levey, 2005). Seeds were defined as damaged or undamaged when more or less than $50 \%$ of the seed coat was harmed. Coats of 20 ingested and 20 uningested S. nigrum seeds were chosen at random for examination by SEM.

\section{Germination experiment}

S. nigrum is a summer annual species with spring- and summer-germinating seeds (Baskin and Baskin, 2001). 
In our study area there are no S. nigrum seedlings in autumn or winter (unpublished results), leading to the assumption of winter dormancy for the collected seeds. Seeds were therefore subjected to a cold stratification treatment before the start of the germination experiment, consisting of groups of 50 seeds spread on two sheets of filter paper soaked with deionized water in Petri dishes, and kept in cold storage at $4^{\circ} \mathrm{C}$ for 7 weeks.

At the end of the dormancy-breaking treatment, 50 full and firm seeds were set to germinate in each Petri dish, laid on two sheets of soaked filter paper. Seeds extracted from different droppings were mixed before starting the germination experiment. Four treatments were carried out: Treatment 1 (T1, $n=9)$, excreted seeds soaked with deionized water $(3 \mathrm{ml})$; Treatment 2 $(\mathrm{T} 2, n=10)$, excreted seeds soaked with bustard manure extract $(3 \mathrm{ml})$; Treatment 3 (T3, $n=10)$, seeds from mature fruits soaked with deionized water $(3 \mathrm{ml})$; and Treatment $4(\mathrm{~T} 4, n=10)$, seeds from mature fruits soaked with pulp extract $(3 \mathrm{ml})$. Petri dishes were randomly distributed in temperature-controlled chambers programmed for a $16 \mathrm{~h}$ light $/ 8 \mathrm{~h}$ dark photoperiod at $25^{\circ} \mathrm{C} / 15^{\circ} \mathrm{C}$, respectively (Baskin and Baskin, 2001). Over a 4-week period, germinated seeds were counted and removed every $3 \mathrm{~d}$. Radicle emergence was the criterion used to record a seed as germinated (Taab and Andersson, 2009). After each count, the Petri dishes were randomly moved between chambers to avoid a chamber position effect. The viability of non-germinated seeds was checked by crushing them with tweezers at the end of the experiment. Empty or rotten seeds were considered not viable. Final germination percentage was defined as germinated seeds divided by total viable seeds and multiplied by 100 . Seed viability percentage was defined as viable seeds divided by total seeds and multiplied by 100 .

\section{Data analysis}

At the end of the experiment, we calculated the germination speed as the time in days until $50 \%$ of germinations occurred in each Petri dish $\left(\mathrm{T}_{50}\right)$. For this purpose, a logistic regression model $y=A[(1+\exp$ $(\beta-k \cdot d a y s)^{-1}$ ] was fitted to the time-germination profiles, where $y$ stands for the cumulative percentage of germinated seeds and $A, \beta$ and $k$ are the estimated parameters of maximum germination percentage $(A)$, the rate parameter $(k)$ and the position of the curve in relation to the time axis $(\beta)$ (Torres and Frutos, 1990). Non-linear regression analyses were calculated for each Petri dish with JMP statistical analysis software (2009; SAS Institute Inc., Cary, North Carolina, USA). The median germination time was calculated for each Petri dish as $\mathrm{T}_{50}=\beta / k$ (Torres and Frutos, 1989, 1990).
The significant effect of treatment on the number of germinated and viable seeds at the end of the experiment and the germination speed was calculated with generalized linear models. We assumed binomial error distribution and logit link function for the number of germinated and viable seeds at the end of the experiment. The significant effect of treatment on germination speed was analysed by quasi-Poisson Generalized Linear Model to deal with overdispersion, assuming Poisson error distribution and log-link function (Zuur et al., 2009). Post-hoc comparisons between treatments were calculated with the Tukey test for all models. The effect of passage through the digestive tract on ingested and non-ingested seed coat damage was analysed with a chi-square test. All the above-mentioned analyses were calculated with R, version 2.15 .0 (http://cran.r-project.org/bin/ windows/base/old/2.15.0/). Results are reported as mean $\pm S D$ in the text and mean \pm SE in the figures.

\section{Results}

Most droppings (83.9\%) contained S. nigrum seeds. We counted $59.8 \pm 44.3$ seeds per dropping and $53 \pm 12$ seeds per fruit (mean \pm SD). Final germination percentages differed significantly between treatments $\left(\chi^{2}=64.32, \mathrm{df}=35, P<0.001\right.$; Fig. $\left.1 \mathrm{~A}\right)$. Germination was significantly lower in ingested seeds than noningested seeds (Fig. 1A; T1 versus T3, $Z=5.887$, $P<0.001)$. There was no significant effect of manure extract on germination percentage of ingested seeds (T1 versus $\mathrm{T} 2, Z=-2.074, P=0.122$ ). There was also no significant effect of Solanum pulp extract on germination percentage of non-ingested seeds (T3 versus $\mathrm{T} 4, Z=0.008, P=1.000$ ).

The germination speed differed significantly between treatments $\left(\chi^{2}=1.48, \mathrm{df}=35, P<0.001\right.$; Fig. 1B). The ingested seeds germinated faster than non-ingested seeds (Fig. $1 \mathrm{~B}$; T1 versus T4: $Z=4.933$, $P<0.001 ; \mathrm{T} 1$ versus T3: $Z=1.892, P=0.231 ; \mathrm{T} 2$ versus T3: $Z=2.802, P=0.026 ;$ T2 versus T4: $Z=5.928, P<0.001)$. There was no significant effect of manure extract on germination speed of ingested seeds (T1 versus $\mathrm{T} 2: Z=-0.837, P=0.836$ ). There was a significant effect of pulp extract on germination speed, the germination of non-ingested seeds with pulp extract was slower than that of non-ingested seeds without pulp (T3 versus T4: $Z=3.162$, $P=0.008)$. Viability percentage differed significantly between treatments $\left(\chi^{2}=32.806\right.$, $\mathrm{df}=35, P<0.001$; Fig. 1C). Ingested seeds had a lower viability percentage than non-ingested seeds (T1 versus $\mathrm{T} 3$ : $Z=4.866, P<0.001)$. There was no significant effect of manure extract on the viability of ingested seeds (T1 versus $\mathrm{T} 2$ : $Z=1.826, P=0.222$ ). There was also no significant effect of pulp extract on viability of 

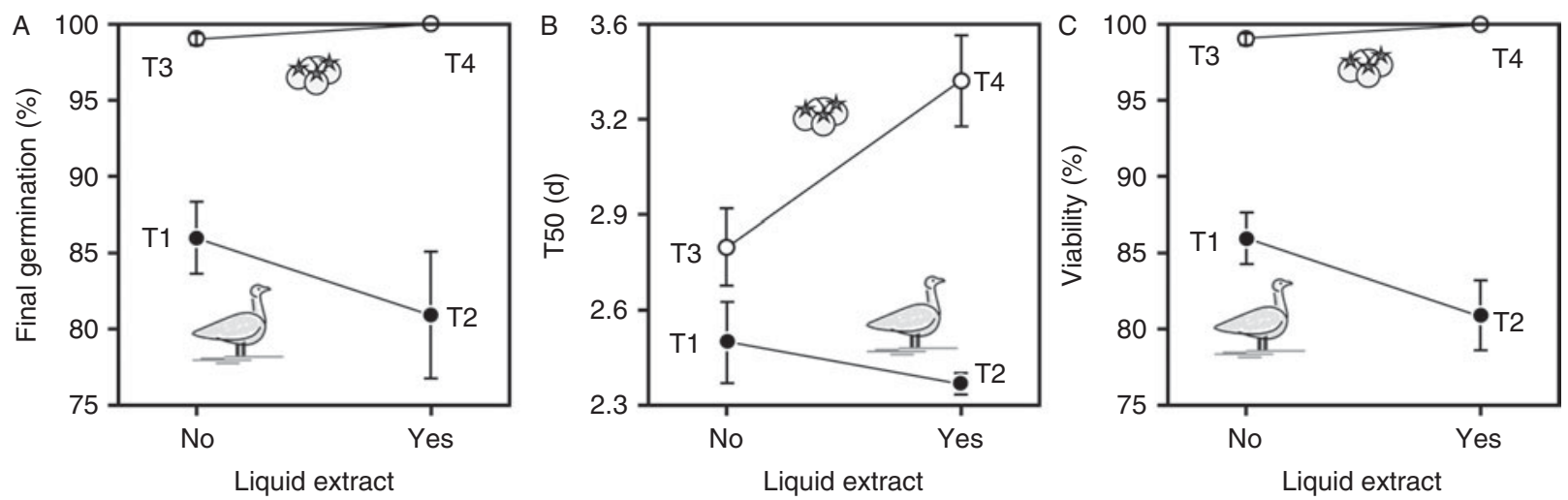

Figure 1. (A) Final germination percentage, $(\mathrm{B})$ germination speed $\left(\mathrm{T}_{50}\right)$ and $(\mathrm{C})$ viability percentage of $S$. nigrum seeds. There were four treatments: ingested seeds (filled symbols) with deionized water (T1) and with bustard manure extract (T2); and non-ingested seeds (empty symbols) with deionized water (T3) and with pulp fruit extract (T4). Means \pm SE are shown.

non-ingested seeds (T3 versus T4: $Z=0.000$, $P=1.000)$. There were significant differences in the presence/absence of damaged seed coats between ingested and non-ingested seeds $\left(\chi^{2}=19.25, \mathrm{df}=38\right.$, $P<0.001$ ) (see supplementary Fig. S1, available online).

\section{Discussion}

This study confirms that a high proportion (84\%) of great bustard droppings contain $S$. nigrum seeds in large quantities (up to $>200$ seeds/dropping). Although great bustard ingestion of S. nigrum seeds decreased the final germination and viability percentages, most seeds survived passage through the great bustard gut and were able to germinate in the laboratory. Great bustards may thus play an important role as S. nigrum seed-disperser vectors on the Iberian Peninsula.

The great bustard is 30 times bigger than the main S. nigrum avian dispersers (blackbirds and starlings). Body size is generally positively correlated with home range area, seed retention time in the gut and quantity of dispersed seeds (Spiegel and Nathan, 2007). Great bustards move across several hectares daily (unpublished results). In late summer, between 15 and $39 \%$ of bustard individuals travel roughly 50-80 km (Palacín et al., 2009), which provides an opportunity for Solanum seeds to disperse over longer distances than via blackbirds and starlings, whose home range areas (Tobler and Smith, 2004; Minderman et al., 2010) are usually smaller than those of great bustards.

The lower viability and final germination percentages of ingested seeds in comparison with noningested ones contrast with previous studies of major S. nigrum disperser species such as blackbirds and starlings. The germination percentage of seeds ingested by these two bird species either increased (Clergeau, 1992; Rodríguez-Pérez et al., 2005) or was unaffected (Barnea et al., 1990; Mas and Traveset, 1999).
Interestingly, in the case of blackbirds and starlings, germination percentage increased when the seed coat was eroded (Clergeau, 1992) but did not increase when this was not the case (Barnea et al., 1990; Mas and Traveset, 1999). The positive effect of scarification on germination in these species could be due to their much smaller digestive systems than that of the great bustard, and thus the physical and chemical scarification of the seeds should also be less intense. Furthermore, small pebbles, grit, cereal seeds and even olive drupes (Olea europaea) have been found in the bustard gut and diet (Bailey et al., 1997; Lane et al., 1999; Delibes et al., 2012). These items, along with the vigorous gizzard of the great bustard, can physically erode the seed coat. In fact, SEM inspection revealed that the ingested seeds used in our experiment bore evidence of physical scarification of the seed coat (see supplementary Fig. S1).

Seed retention time in the digestive tract also influences the germination of ingested seeds and depends on the disperser's diet and body size (Jackson, 1992; Afik and Karasov, 1995). Longer gut retention may reduce seed viability and germination percentages over shorter periods (Charalambidou et al., 2003). To our knowledge, seed retention time is unknown in any bustard species, but is probably longer than in blackbirds and starlings due to their different body size and diet type. It has been shown that herbivorous bird species with caecal fermentation, such as the bustard family (Otididae), have a longer retention time than frugivorous or omnivorous species (Karasov, 1990; DeGolier et al., 1999). In fact, some studies of seed dispersal effectiveness in geese (herbivorous diet and caecal fermentation) have described a decrease in seed germination percentage after gut passage (Chang et al., 2005; Figuerola et al., 2010).

Germination speed of ingested seeds was higher than that of non-ingested seeds. Roughly $80 \%$ of the ingested seeds germinated in $3 \mathrm{~d}$, in contrast to $6 \mathrm{~d}$ in the case of $80 \%$ of the non-ingested seeds (Fig. 2). 


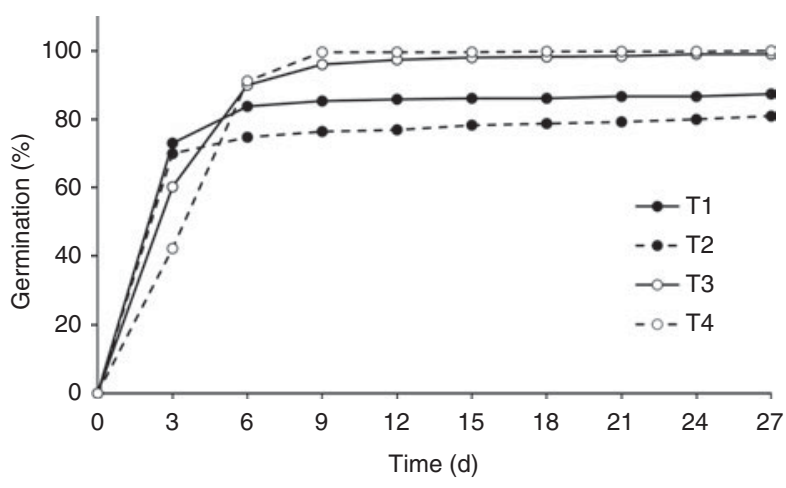

Figure 2. Cumulative mean proportions of germinated Solanum nigrum seeds for each treatment. There were four treatments: ingested seeds (filled symbols) with deionized water (T1) and with bustard manure extract (T2); and noningested seeds (empty symbols) with deionized water (T3) and with pulp fruit extract (T4). Dashed lines show seeds with manure or pulp extract. Solid lines show seeds without extract.

Likewise, more than $80 \%$ of $S$. nigrum seeds germinated within $3 \mathrm{~d}$ after ingestion by blackbirds and Sardinian warblers (Sylvia melanocephala) (Mas and Traveset, 1999). Although these bird species did not accelerate germination in this experiment, they did so in a second one (Rodríguez-Pérez et al., 2005). The increase in germination speed due to endozoochory is a recurrent result in most studies of germination (Traveset and Verdú, 2002), and great bustards follow this pattern. Increased germination speed might not be related to fitness because early germinated seeds could be more likely to die due to other factors, such as desiccation, pathogens or predators (Traveset, 1998; Traveset et al., 2007). It is unclear whether short time periods, such as the difference in germination speed between ingested and non-ingested seeds induced by great bustard ( $3 \mathrm{~d}$ ) or even by blackbirds (RodríguezPérez et al., 2005), are meaningful in an ecological context. In central Spain, S. nigrum germinates in late spring, a period of high desiccation risk, and unless an increase in plant fitness can be shown, it is difficult to support the claim that an increase in germination speed is advantageous (Traveset, 1998). On the other hand, the deposition site of the ingested seed may determine the ultimate success of the seedling and future plant (Schupp et al., 2010; Rey and Alcántara, 2014).

The fertilizing effect of the great bustard's droppings on final germination, germination speed and viability of the ingested seeds was not significant, contrary to our prediction and previous studies (Traveset et al., 2007). The null effect was unusual because manure surrounding deposited seeds is considered to enhance germination by providing nutrients, such as nitrogen, which stimulate germination (Luna and Moreno, 2009), or to diminish germination due to the growth of bacteria and fungi and/or phytotoxicity, facilitated by some components of the excrement (Hoekstra et al., 2002). The same preparation and spraying of a manure extract was successfully applied in previous studies (Carmona et al., 2013). We also discard the lack of effect due to a low manure concentration in our extract, given that the presence of the manure extract (regardless of concentration) did affect germination in previous studies (Carmona et al., 2013).

The releasing effect of the elimination of the fruit pulp was not detected, since the germination percentages in clean seeds and seeds sprayed with pulp extract were not significantly different. The pulp extract probably lost key volatile secondary metabolites responsible for inhibition (Cipollini and Levey, 1997) when the fruits were dried at $80^{\circ} \mathrm{C}$ for $72 \mathrm{~h}$. Nonetheless, the germination speed was reduced by the pulp extract (Fig. 1B), which indicates that the pulp extract worked as hypothesized. The lack of an inhibitory effect of the pulp on final germination is contrary to the results of previous studies, where final germination of seeds with pulp is usually lower than that of clean seeds (Cipollini and Levey, 1997; Meyer and Witmer, 1998; Robertson et al., 2006). The method used to assess the pulp effect was probably not the most suitable, as previous studies exploring this aspect used intact fruits (Barnea et al., 1991; Cipollini and Levey, 1997; Meyer and Witmer, 1998; Robertson et al., 2006). The pulp extract concentration (1:10) was probably not strong enough to inhibit germination or break the high osmotic pressure of the seed, and thus did not prevent its water absorption (Mayer and Poljakoff-Mayber, 1989). Removal of S. nigrum pulp slowed germination, but no further conclusions can be drawn from the effects of pulp extract on the germination percentage or viability.

In order to understand the role of the great bustard in plant recruitment, we need to dissect the components of dispersal effectiveness. In our study, we estimated some of the quality components of seed dispersal effectiveness. Great bustards have a negative effect on the germination of S. nigrum seeds, although the seeds still germinate in large numbers and double their germination speed. Further research combining the effect of ingestion on seed germination with the microhabitat effect of the seed deposition site should be carried out to understand the disperser quality of the seed consumer species. In addition, it must be stressed that a fuller understanding of seed dispersal mechanisms is necessary in order to define the factors involved in agricultural ecosystems (Benvenuti, 2007).

\section{Supplementary material}

To view supplementary material for this article, please visit http:/ / dx.doi.org/10.1017/S0960258514000178 


\section{Acknowledgements}

We thank Manuela Gallardo (MNCN-CSIC histology lab) for her advice and help during the laboratory preparation of samples.

\section{Financial support}

Financial support was provided by the Dirección General de Investigación, Spanish Ministry for Science and Innovation, under projects CGL2008-02567 and CGL2011-24871. C.B. was supported by a HenarsaCSIC (Consejo Superior de Investigaciones Científicas) contract.

\section{Conflicts of interest}

None.

\section{References}

AEMET (2014) Agencia Estatal de Meteorología. Available at http:/ / www.aemet.es/es/serviciosclimaticos/datosclimatologicos / (accessed June 2013)

Afik, D. and Karasov, W.H. (1995) The trade-offs between digestion rate and efficiency in warblers and their ecological implications. Ecology 76, 2247-2257.

Alonso, J.C., Magaña, M., Alonso, J.A., Palacín, C., Martín, C.A. and Martín, B. (2009) The most extreme sexual size dimorphism among birds: allometry, selection, and early juvenile development in the great bustard (Otis tarda). The Auk 126, 657-665.

Bailey, T.A., Mensah-Brown, E.P., Samour, J.H., Naldo, J., Lawrence, P. and Garner, A. (1997) Comparative morphology of the alimentary tract and its glandular derivatives of captive bustards. Journal of Anatomy 191, 387-398.

Barnea, A., Yomtov, Y. and Friedman, J. (1990) Differential germination of two closely related species of Solanum in response to bird ingestion. Oikos 57, 222-228.

Barnea, A., Yomtov, Y. and Friedman, J. (1991) Does ingestion by birds affect seed-germination? Functional Ecology 5, 394-402.

Baskin, C.C. and Baskin, J.M. (2001) Seeds. San Diego, USA, Academic Press.

Bautista, L.M., Silván, G., Cáceres, S., Martínez-Fernández, L., Bravo, C., Illera, J.C., Alonso, J.C. and Blanco, G. (2013) Faecal sexual steroids in sex typing and endocrine status of great bustards. European Journal of Wildlife Research 59, $815-822$.

Benvenuti, S. (2007) Weed seed movement and dispersal strategies in the agricultural environment. Weed Biology and Management 7, 141-157.

Bravo, C., Ponce, C., Palacín, C. and Carlos Alonso, J. (2012) Diet of young Great Bustards Otis tarda in Spain: sexual and seasonal differences. Bird Study 59, 243-251.

Carmona, C.P., Azcárate, F.M. and Peco, B. (2013) Does cattle dung cause differences between grazing increaser and decreaser germination response? Acta OecologicaInternational Journal of Ecology 47, 1-7.

Chang, E.R., Zozaya, E.L., Kuijper, D.P.J. and Bakker, J.P. (2005) Seed dispersal by small herbivores and tidal water: are they important filters in the assembly of saltmarsh communities? Functional Ecology 19, 665-673.

Charalambidou, I., Santamaria, L. and Langevoord, O. (2003) Effect of ingestion by five avian dispersers on the retention time, retrieval and germination of Ruppia maritima seeds. Functional Ecology 17, 747-753.

Cipollini, M.L. and Levey, D.J. (1997) Secondary metabolites of fleshy vertebrate-dispersed fruits: Adaptive hypotheses and implications for seed dispersal. American Naturalist 150, 346-372.

Clergeau, P. (1992) The effect of birds on seed-germination of fleshy-fruited plants in temperate farmland. Acta Oecologica-International Journal of Ecology 13, 679-686.

DeGolier, T.F., Mahoney, S.A. and Duke, G.E. (1999) Relationships of avian cecal lengths to food habits, taxonomic position, and intestinal lengths. Condor 101, 622-634.

Delibes, M., Corbacho, C., Calvo, G. and Fedriani, J.M. (2012) Agriculture as matchmaker of an unexpected mutualism: Great bustard disperses and enhances emergence of domestic olive seeds. Basic and Applied Ecology 13, 125-131.

Dinerstein, E. and Wemmer, C.M. (1988) Fruits rhinoceros eat - dispersal of Trewia nudiflora (Euphorbiaceae) in lowland Nepal. Ecology 69, 1768-1774.

Estrada, A. and Fleming, T.H. (1986) Frugivores and seed dispersal. Dordrecht, Dr W. Junk Publishers.

Figuerola, J., Charalambidou, I., Santamaria, L. and Green, A.J. (2010) Internal dispersal of seeds by waterfowl: effect of seed size on gut passage time and germination patterns. Naturwissenschaften 97, 555-565.

Herrera, C.M. (2002) Seed dispersal by vertebrates. pp. 185-208 in Herrera, C.M.; Pellmyr, O. (Eds) Plant-animal interactions: An evolutionary approach. New York, Blackwell.

Hoekstra, N.J., Bosker, T. and Lantinga, E.A. (2002) Effects of cattle dung from farms with different feeding strategies on germination and initial root growth of cress (Lepidium sativum L.). Agriculture Ecosystems $\mathcal{E}$ Environment 93, 189-196.

Howe, H.F. and Smallwood, J. (1982) Ecology of seed dispersal. Annual Review of Ecology and Systematics 13, 201-228.

Jackson, S. (1992) Do seabird gut sizes and mean retention times reflect adaptation to diet and foraging method? Physiological Zoology 65, 674-697.

Jordano, P. and Schupp, E.W. (2000) Seed disperser effectiveness: The quantity component and patterns of seed rain for Prunus mahaleb. Ecological Monographs 70, 591-615.

Karasov, W.H. (1990) Digestion in birds: chemical and physiological determinants and ecological implications. pp. 391-415 in Morrison, M.L.; Ralpa, C.J.; Verner, J.; Jehl, J.J.R. (Eds) Avian foraging theory, methodology and applications: Studies in avian biology. San Diego, California, USA, Cooper Ornithological Society Publishing.

Lane, S.J., Alonso, J.C., Alonso, J.A. and Naveso, M.A. (1999) Seasonal changes in diet and diet selection of great bustards (Otis tarda) in north-west Spain. Journal of Zoology 247, 201-214.

Lucio, A.J. (1985) Datos sobre la alimentación de la avutarda (Otis tarda L. 1758) en la Cuenca del Duero. Alytes 3, 69-86. 
Luna, B. and Moreno, J.M. (2009) Light and nitrate effects on seed germination of Mediterranean plant species of several functional groups. Plant Ecology 203, 123-135.

Mas, R.E. and Traveset, A. (1999) Efectes de la ingestió per ocells sobre la germinació i la dispersió de dues espècies próximes de Solanum. Bolletí de la Societat d'Història Natural de les Balears 42, 69-77.

Mayer, A.M. and Poljakoff-Mayber, A. (1989) The germination of seeds. New York, Pergamon Press.

Meyer, G.A. and Witmer, M.C. (1998) Influence of seed processing by frugivorous birds on germination success of three North American shrubs. American Midland Naturalist 140, 129-139.

Minderman, J., Reid, J.M., Hughes, M., Denny, M.J.H., Hogg, S., Evans, P.G.H. and Whittingham, M.J. (2010) Novel environment exploration and home range size in starlings Sturnus vulgaris. Behavioral Ecology 21, 1321-1329.

Palacín, C., Alonso, J.C., Alonso, J.A., Martín, C.A., Magaña, M. and Martín, B. (2009) Differential migration by sex in the Great Bustard: Possible consequences of an extreme sexual size dimorphism. Ethology 115, 617-626.

Rey, P.J. and Alcántara, J.M. (2014) Effects of habitat alteration on the effectiveness of plant-avian seed dispersal mutualisms: consequences for plant regeneration. Perspectives in Plant Ecology Evolution and Systematics 16, 21-31.

Robertson, A.W., Trass, A., Ladley, J.J. and Kelly, D. (2006) Assessing the benefits of frugivory for seed germination: the importance of the disinhibition effect. Functional Ecology 20, 58-66.

Rodríguez-Pérez, J., Riera, N. and Traveset, A. (2005) Effect of seed passage through birds and lizards on emergence rate of Mediterranean species: differences between natural and controlled conditions. Functional Ecology 19, 699-706.

Samuels, I.A. and Levey, D.J. (2005) Effects of gut passage on seed germination: do experiments answer the questions they ask? Functional Ecology 19, 365-368.

Schupp, E.W. (1993) Quantity, quality and the effectiveness of seed dispersal by animals. Advances in Vegetation Science 15, 15-29.

Schupp, E.W., Jordano, P. and Maria Gomez, J. (2010) Seed dispersal effectiveness revisited: a conceptual review. New Phytologist 188, 333-353.
Spiegel, O. and Nathan, R. (2007) Incorporating dispersal distance into the disperser effectiveness framework: frugivorous birds provide complementary dispersal to plants in a patchy environment. Ecology Letters 10, 718-728.

Taab, A. and Andersson, L. (2009) Seed dormancy dynamics and germination characteristics of Solanum nigrum. Weed Research 49, 490-498.

Tobler, M. and Smith, H.G. (2004) Specific floater home ranges and prospective behaviour in the European starling, Sturnus vulgaris. Naturwissenschaften 91, 85-89.

Torres, M. and Frutos, G. (1989) Analysis of germination curves of aged fennel seeds by mathematical models. Environmental and Experimental Botany 29, 409-415.

Torres, M. and Frutos, G. (1990) Logistic function-analysis of germination behavior of aged fennel seeds. Environmental and Experimental Botany 30, 383-390.

Traveset, A. (1998) Effect of seed passage through vertebrate frugivores' guts on germination: a review. Perspectives in Plant Ecology Evolution and Systematics 1, 151-190.

Traveset, A. and Verdú, M. (2002) A meta-analysis of the effect of gut treatment on seed germination in Levey, D.J.; Silva, W.R.; Galetti, M. (Eds) Seed dispersal and frugivory: ecology, evolution and conservation. New York, CAB International.

Traveset, A., Riera, N. and Mas, R.E. (2001) Passage through bird guts causes interspecific differences in seed germination characteristics. Functional Ecology 15, 669-675.

Traveset, A., Robertson, A.W. and Rodríguez-Pérez, J. (2007) A review on the role of endozoochory in seed germination. pp. 78-103 in Dennis, A.J.; Schupp, E.W.; Green, R.J.; Westcott, D.A. (Eds) Seed dispersal: theory and its application in a changing world. Wallingford, UK, CAB International.

Willson, M.F. and Traveset, A. (2000) The ecology of seed dispersal. pp. 85-110 in Fenner, M. (Ed.) Seeds: the ecology of regeneration in plant communities. New York, CAB International.

Zuur, A.F., Ieno, E.N., Walker, N.J., Saveliev, A.A. and Smith, G.M. (2009) Mixed effects models and extensions in ecology with $R$. New York, Springer. 


\section{Supplementary material}

Supplementary figure 1. Micrographs of digested (A, B) and non-digested (C, D) seed coat of Solanum nigrum.
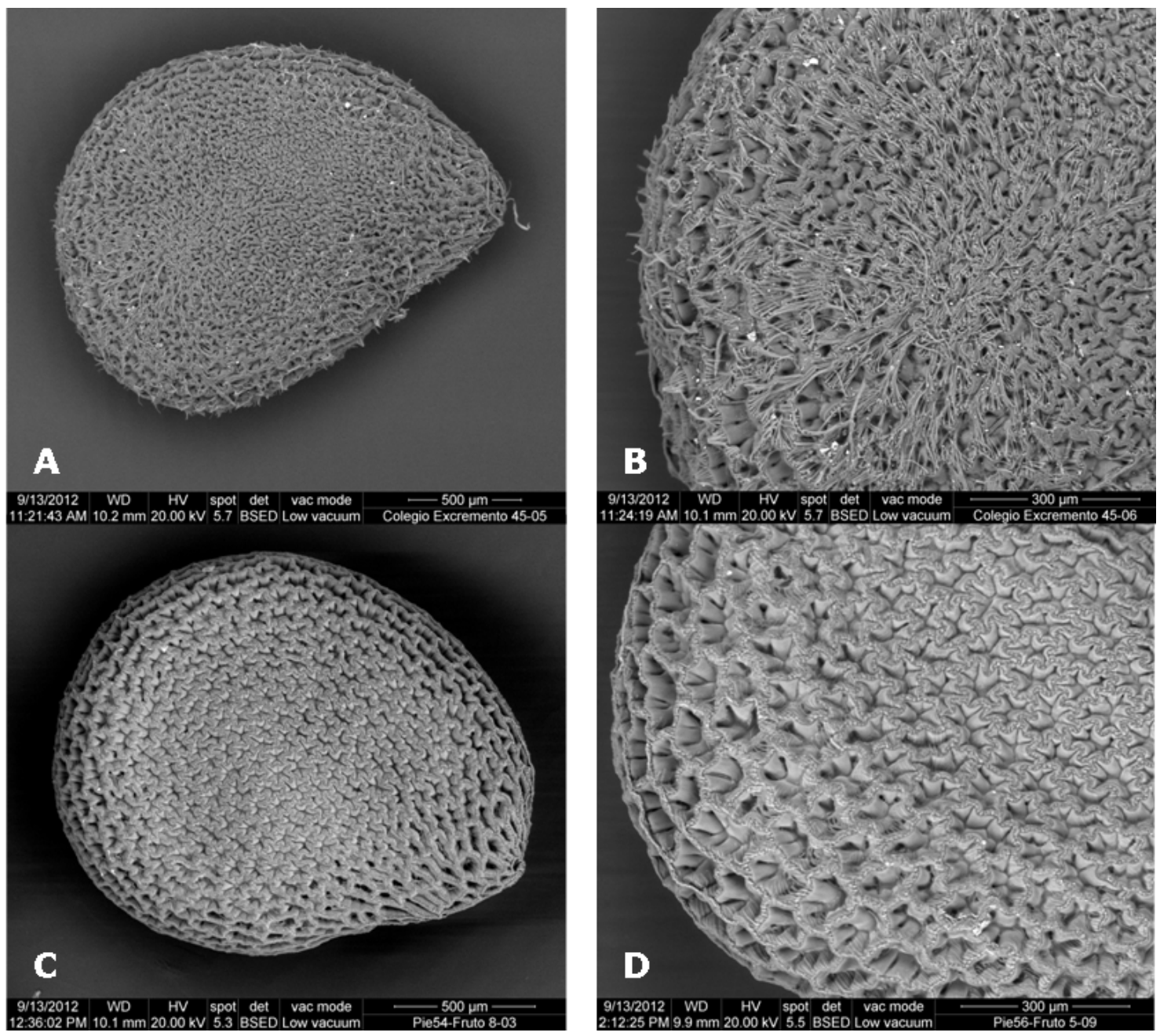